\title{
Strategic Human Resource Development for Enhanced Job Performance and Universities' Competitiveness
}

\author{
1Falola, H.O \\ 2Abasilim U. D \\ 3Salau, O.P \\ 1,3 Department of Business Management, Covenant University, Ota, Ogun State, Nigeria \\ ${ }^{2}$ Department of Political Science and International Relations, Covenant University, Ota, Ogun State, Nigeria
}

\section{Doi:10.5901/mjss.2016.v7n3p89}

\begin{abstract}
Human resource development strategy is considered to be an indispensable strategic tool for enhancing employee job performance and organisation's competitiveness. The main objective of this study is to examine the strategic role of human resource development on employee performance and organisational competitiveness in private universities. A descriptive research method (Structural Equation Model (AMOS 21)) was applied, to analyse the three hundred and fifty seven (357) valid questionnaires which were completed by the academic staff of the selected universities using stratified and simple random sampling techniques. The results show closed relationships between the dependent variable and independent variables. However, the study indicated that executive advance, mentoring, research collaboration and academic linkage, organisational learning and induction/orientation have positive effects on teaching, research, innovation and community service and subsequently impact on faculty performance and organisational competitiveness.
\end{abstract}

Keywords: Development, Executive Advance, Human resource, Mentoring, Organisational Learning Research, Teaching

\section{Introduction}

The most valuable asset and backbone of any organisation including educational sector is its human resources, however, attracting and developing skilled faculty and staff remains sine-qua-non essential for Universities survival and sustainable development (Adeniji, Falola and Salau, 2014). The central idea underlying strategic human resource development in institutions of higher learning, is how best to keep the faculty and staff current and versatile for effective performance (Peretomode, and Chukwuma, 2012). The need for faculty to improve and update their knowledge and skills to keep abreast of the trends of knowledge development in their discipline is more crucial in Nigerian Universities to adequately prepare employable candidates (Peretomode and Peretomode, 2001). The Universities comprise of faculty members engaged with institutional services such as; teaching, research, innovation and community impact while the non-teaching staff are administrative and technical staff providing support services to the academic staff. The fundamental role of Universities in building a strong economy and society coupled with the evolving competition in higher education institutions around the globe, has called for good, robust and strategic execution of effective human resource development to compete favourably with their counterpart in the developed world (Falola, Osibanjo and Ojo, 2014; Saxena, 2012; Obisi, 2001). Strategic human resource development set out what the Universities intend to do to equip their faculty members and non-teaching staff with skills, knowledge and competencies they require to undertake the immediate and future tasks required by the University (Werner and DeSimone, 2006; Walton, 1999) and how they should be integrated into the University's overall strategies (Armstrong, 2009). Strategic human resource development as noted by Armstrong (2010), takes a clear vision of employees' abilities, capabilities, competence and long term view of how human resource development policies can support the objective and mission of the university's operation strategies. Meanwhile, Strategic human resource development of University academic and non-academic staff requires a comprehensive framework to create a learning culture and strategic policies that will enhance employee intellectual capacity and performance for a competitive advantage (Vemic, 2007; Edralin, 2004). Strategic human resource development is an aspect of strategic human resource management practice that help improving employees' skills, and capabilities (Palo and Padhi, 2003). Human resource development plays a vital role in the effectiveness and competitiveness of institutions of higher learning (Goldstein and Ford, 2002) as well providing opportunities to learn 
necessary skills to meet current and future job demands (Werner and DeSimone, 2006)

Universities' survival and sustainability in the competitive environment requires strategic development of faculty and staff with distinctive ability and disposition for excellence to achieve a competitive edge (Deros, Rahman, Nizam, Rahman, Ismail, and Said, 2008, Gardner, 2002). Therefore, University's management must have the capability not only to identify competent, experience and talented individuals, but must intensify efforts to providing relevant learning and development (McCauley and Wakefield, 2006). According to Ntanga (2007), strategic human resource development becomes imperative because universities' rapid growth and sustainable development often require different kinds of skills and innovation that must be integrated and aligned with the University's overall goals. Besides, Universities are expected to respond to the changes in their competitive environments by identifying types of employees' skills development needed at present and in the future to ensure consistent growth and sustainable development (Amankwah-Amoah, and Debrah, 2011). Human resource development however becomes imperative for employee job performance and organisational competitive advantage (Elegbe, 2010).

In line with the afore-mentioned, the study become necessary to examine the effect of strategic human resource development on job performance and organisation competitiveness with specific reference to private universities in Ogun State, Nigeria. It is also important to verify claims like employee intellectual capacity development is crucial to University's strategic success (Rose and Kumar, 2006; Frank and Taylor, 2004; Lawlar and Mohraman, 2003). Universities cannot be successful without effective strategic human resource development that can spur optimal performance and maximize the possibility of achieving overall strategic objective (Mendez and Stander, 2011). The importance of this study stemmed from its objectives as follows:

- To examine how executive advance can enhance teaching and research qualities in the university system

- To analyse the extent to which mentoring strategy impact research publications

- To evaluate the extent to which of collaboration and academic linkages impact research, innovation and performance

- To analyse the effect of organisational learning on innovation and community impact

- To examine whether induction/orientation strategy can promote innovation and community service

\subsection{The Significance of the Study}

The strategic human resource development for enhanced job performance and organisational performance became necessary to reposition Nigerian Universities to compete favourably with their counterpart around the globe. The study helps identify the challenges and subsequently proffer suggestions that will help the stakeholders to understand the strategic human resource development approaches to adopt for effective job performance; it will help in identifying effective and efficient development strategies that will lead to improve performance; the education sector in Nigeria will be better positioned and structured to compete with the outside world; the academic researchers will be provided a platform for further investigation on the subject matter.

\section{Literature Review}

\subsection{Faculty Executive Advance and Pedagogical Teaching and Research}

Executive advance in this context refers to academic conferences, retreat, seminars, symposium etc. These are strategic platforms upon which faculty members of the Universities can be developed and equipped with updated skills, knowledge and competences (Peretomode and Chukwuma, 2012). Meanwhile, executive advance is not only a platform for lecturer's reflection, recharging and rejuvenation, it is also designed to share institutional ideas, experiences and valuable insight. As noted by Macfarlane (2010), executive advance provides learning opportunities for lecturers to enrich their teaching and research qualities through hand-on learning, plenary sessions, keynote addresses, latest research presentations, faculty development and instructional design among others. Executive advance tends to influence teaching and pedagogical research, therefore the study propose the following hypotheses:

$H_{1}$ : Executive advance has positive impact on faculty teaching quality

$\mathrm{H}_{2}$ : executive advance has positive impact on faculty research pedagogy 


\subsection{Mentoring and Quality of Teaching/Research}

Mentoring is a strategic plans specifically designed by University management to train and retain highly competent faculty for quality teaching and robust research through mentee-mentor relationship (Hegstad and Wentling, 2004). Most Universities see the need for regular and timely mentoring and workplace learning to enhance quality teaching and research performance to promote sustainability and competitive advantage (Darwin, 2000). Meanwhile, Whelan and Carcary (2011) opined that mentoring facilitate career progression, psychological support and personal development which invariably transient faculty productive engagement in teaching, innovation and research, satisfaction and retention (Emelo, 2009; Lo and Ramayah, 2011; Weinberg and Lankau, 2011). Mentor-mentee relationship is likely to reduce absenteeism (Judge and Kammeyer-Mueller, 2011), promote effective utilisation of talented and competent faculty (lles, Preece and Chuai 2010; Francis, 2009) and improve team work, academic linkages and collaboration (Bamford, 2011; Bozeman and Feeney, 2007; Holland, 2009). In another development, Mentoring is closely associated with career enhancement and development of academic staff (MacGregor, 2000; Weinberg and Lankau, 2011); evaluate their current competencies, identify gaps, and develop strategies to gain new or required competencies (Lo and Ramayah, 2011). Further to the literature reviewed mentoring tends to influence quality teaching and research, therefore we propose the following hypothesis:

\section{$H_{3}$ : mentoring has positive impact on faculty teaching quality and research performance}

\subsection{Research Collaboration and Academic Linkages}

Brew (2010) posited that research collaboration and academic linkage is another strategic platform upon which faculty competences and capabilities can be enhanced for productive teaching, research and academic innovation. However, research collaboration from different or related disciplines and countries is paramount and more likely to have positive impact on lecturers' performance (Amabile, Patterson, Mueller, Wojcik, Kramer, Odomirok, 2001). Meanwhile, academic linkages and research collaboration are likely to provide a platform for knowledge transfer that will enrich quality teaching and research (Burke and Rau, 2010). In a related development, research collaboration and academic linkages are capable of enhancing lecturers intellectualism which allows them to keep updated on learning and teaching integration skills, pedagogical research, sharing valuable ideas and experiences (Griffths, 2004; Leisyte, Enders and Boer, 2009). Sequel to the literature reviewed, we therefore propose the following hypothesis:

$\mathrm{H}_{4}$ : there is positive impact of research collaboration and academic linkage on faculty research quality and innovation

\subsection{Organisation Learning, Innovation and Community Service}

What a university knows and how well they are able to utilise the knowledge gathered determines the success and survival of such institution (Lengnick-Hall and Inocencio-Gray, 2013; Grant, 1996). Learning is a necessity for Universities to compete favourably in the ever-changing competitive environment to ensure sustainable development (Chadwick and Raver, 2015; Edmondson, 2008). Besides, Organizational learning is a strategic process that enables the lectures to learn and react to environmental dynamism via better knowledge and understanding (Edmondson, 2002; Giles and Hargreaves, 2006 and Louis, 2006). However, the University capability for innovation, research and community service relies on the faculty ability to collectively learn organisational rudiments, process and apply their skills and experiences accordingly (Kruse, 2003; Silins and Mulford, 2002). Organisation learning is likely to offer great opportunities for lecturers to learn and improve on their research skills for innovation and better performance (Putz, Schilling, Kluge, and Stangenberg, 2012). It is on this premise that we propose the following hypothesis:

$H_{5}$ : Organisation learning has positive impact on faculty level of innovation and community service

\subsection{Induction and Orientation on Lecturers Performance}

Organisations including education sector usually put in place some form of induction or orientation training programme for new employees for proper integration into the system (Mlindazwe 2010; Hendricks and Louw- Potgieter, 2012). Induction/orientation has become one of the fundamental strategic tool for human resource development in this cotemporary world of competitiveness (Klein and Weaver, 2000). It also offers the new employees the opportunity to know the core values, culture, ethics of the University and reducing the likelihood of breaching the institution policies (Salau, Falola and Akinbode, 2014; Kearney, 2010). The induction/orientation of new academic staff provides a platform 
for lecturers to equip themselves with theoretical and practical knowledge for improve performance in teaching, research, innovation and community impact (Ndebele, 2013). Therefore we propose the following hypothesis:

$\mathrm{H}_{6}$ : induction and orientation have positive impact on faculty performance

\subsection{Research Model}

This study will focus on the effects of strategic human resource development on job performance and organisational competitiveness in Nigerian private Universities. However, as obtained in the literature reviewed, we propose the research model depicted in figure 1.

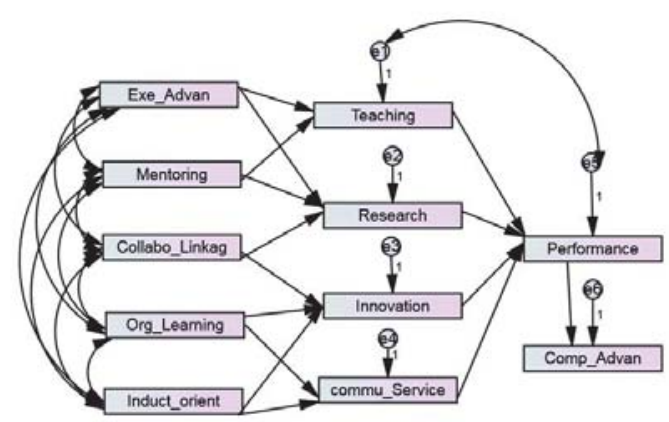

Figure 1: Proposed Study Model

\subsection{Research Methods}

The data for this study were collected from a survey of academics staff in private Universities located in south-west Nigeria. However, the choice of the private universities in south west Nigeria was based on high concentration of most private Universities in Nigeria. Meanwhile, the private Universities chosen for this study were the best four (4) private universities in South-West, Nigeria as ranked by 2014 webometric ranking. The Universities are Covenant University, Afe Babalola University, Lead City University and Redeemer's University. Both senior and junior academics staff ranging from graduate assistant to full professorial cadre within different age groups, marital status, and diverse academic qualifications with appreciable work experience completed the questionnaire administered to them. Meanwhile, five hundred (500) questionnaire was administered but only three hundred and fifty seven (357) copies were retrieved representing $71 \%$ response rate. Strategic human resource development was measured using 27 -item instrument which was divided into sections A and B. Section A comprised of 7 items which was used to gather respondents demographic information such as gender, age, marital status, educational qualification, years of experience etc. section B contained 20 items regarding the constructs of the subject matter. Five-point Likert scale (5-Strongly Agreed, 4- Agree, 3Undecided, 2-Strongly Disagree, 1-Disagree) that best describes the extent to which the respondents agree with each item in the questionnaire. The descriptive statistics were used to calculate the demographic variables. The analysis was done using Statistical Package for Social Sciences (SPSS) AMOS 21, and Structural Equation Modeling (SEM) was used to determine the strength of relationship between observed variables and also regression between the dependent and independent constructs of the study.

\section{Discussion of Result}

\section{Respondents Demography}

Table I: Demographic and Socio-economic Characteristics of Respondents

\begin{tabular}{|l|c|c|}
\hline & Frequency & Percentage \\
\hline Gender: & 291 & 81.5 \\
\hline Male & \multicolumn{3}{|c|}{} \\
\hline
\end{tabular}




\begin{tabular}{|c|c|c|}
\hline Female & 66 & 18.5 \\
\hline & 357 & 100 \\
\hline \multicolumn{3}{|l|}{ Age: } \\
\hline $20-29$ & 77 & 21.6 \\
\hline $30-39$ & 101 & 28.2 \\
\hline $40-49$ & 127 & 35.6 \\
\hline 50 years and above & 52 & 14.6 \\
\hline Total & 357 & $100 \%$ \\
\hline \multicolumn{3}{|l|}{ Position/Rank } \\
\hline Professor & 22 & 6.2 \\
\hline Associate Professor & 31 & 8.7 \\
\hline Senior Lecturer & 58 & 16.2 \\
\hline Lecturer 1 & 83 & 23.2 \\
\hline Lecturer II & 87 & 24.4 \\
\hline Assistant Lecturer & 64 & 17.9 \\
\hline Graduate Assistant & 12 & 3.4 \\
\hline Total & 357 & $100 \%$ \\
\hline
\end{tabular}

Source: Researcher's Analysis of Field Survey, 2014

Following from table 1, $81.5 \%$ of the respondents were males and $18.7 \%$ were females. The reason for this is that the Nigerian University is dominated by male faculty (Gberevbie, Osibanjo, Adeniji, and Oludayo, 2014). Furthermore, about $87.4 \%$ (cumulative percentage) of the respondents were within the productive age range. Also, position/rank distribution of respondents indicates that $14.9 \%$ (cumulative percentage) of the respondents were within professorial cadre, $16.2 \%$ were at the senior lecturer category, while 68.9 cumulative percent represents the respondents at the lower level cadre ranging from Lecturer 1 to Graduate Assistant

Table 2: Estimates of Covariance among Exogenous Variables

\begin{tabular}{|c|c|c|c|c|c|c|c|}
\hline & & & Estimate & S.E. & C.R. & $P$ & Label \\
\hline Teaching & $<--$ & Exe_Advan & .184 & .036 & 3.994 & $\star \star \star$ & Significant \\
\hline Teaching & $<--$ & Mentoring & .130 & .074 & 1.729 & .084 & Significant \\
\hline Research & $<--$ & Mentoring & .021 & .054 & .387 & .699 & Significant \\
\hline Research & $<--$ & Collabo_Linkag & .028 & .044 & .451 & .652 & Significant \\
\hline Innovation & $<--$ & Org_Learning & .107 & .035 & 2.034 & .042 & Significant \\
\hline commu_Service & $<--$ & Induct_orient & .091 & .047 & 1.729 & .084 & Significant \\
\hline Innovation & $<--$ & Induct_orient & -.169 & .033 & -3.293 & $\star \star \star ~$ & Not Significant \\
\hline Innovation & $<--$ & Collabo_Linkag & .116 & .039 & 2.196 & .028 & Significant \\
\hline Research & $<--$ & Exe_Advan & .155 & .049 & 2.489 & .013 & Significant \\
\hline commu_Service & $<--$ & Org_Learning & .079 & .048 & 1.499 & .134 & Significant \\
\hline Performance & $<--$ & Teaching & .539 & .243 & 1.538 & .124 & Significant \\
\hline Performance & $<--$ & Research & .003 & .034 & .051 & .959 & Significant \\
\hline Performance & $<--$ & Innovation & .138 & .032 & 2.769 & .006 & Significant \\
\hline Performance & $<--$ & commu_Service & .373 & .026 & 6.656 & $\star \star * \star$ & Significant \\
\hline Comp_Advan & $<--$ & Performance & .484 & .103 & 10.573 & $* \star *$ & Significant \\
\hline
\end{tabular}

Note: C.R. = Critical Ratio; S.E. = Standard Error; * significant at 0.05

Based on the acquired results, it was found that there were significant contribution models between the four dimensions of human resource development strategy namely executive advance, mentoring, collaboration and academic linkages, organisation learning and induction on research, teaching, innovation and community impact. Table 2 above shows the significant correlation between variables. 


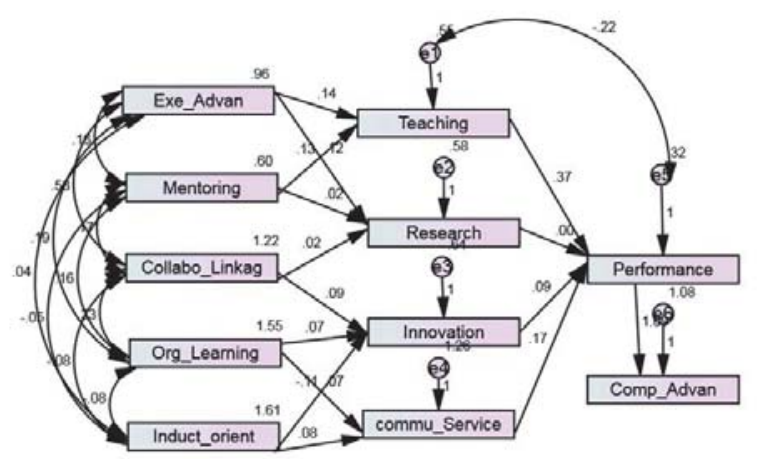

Figure 2: Results of the Structural Model of the Data Collected

\subsection{Model Testing}

Structural equation model analysis (SEM) was adopted to test relationship observed and latent variables of the proposed hypothesises to determine the level of fitness. Model fit indices such as Comparative Fit Index (CFI); Normed Fit Index (NFI); Relative Fix Index (RFI); Incremental Fix Index (IFI); Root Mean Square Error of Approximation (RMSEA); CMIN indicated acceptable and good fit. As noted by Tabachinck and Fidell (2007); Hu and Bentlar (1999) and Bentler and Bonett (1980), acceptable model fit benchmark value for the indices is 0.90 or greater. However, the result obtained shows that all the fits indices are above the minimum acceptable value indicating a good fit. The fit index are as follows: $\mathrm{NFI}=.989 ; \mathrm{CFI}=.988 ; \mathrm{IFI}=.995$.

Further to the result of the structural model depicted in figure 2, the model result show the regression between Executive Advance (Exe_Advan); mentoring; Research Collaboration and Academic Linkages (Collabo_Linkage); Organisational Learning (Org_Learning) and Induction and Orientation (Induct_Orient) on job performance and organisational competitiveness. Besides, all the variables tested under independent construct have positive path coefficients with the exception of induction/orientation as factors that tend to enhance job performance and organisational competitiveness. However, the path coefficient scores (regression weights) of the observed constructs explain the regression between the studied variables. The regression weight between executive advance and teaching is .184 $(p<0.001)$ which indicate that when executive advance goes up by 1 (standard deviation), teaching goes up by 0.184 (standard deviations). Meanwhile, the regression weight for executive advance in the prediction of faculty teaching skills is significantly different from zero at the 0.001 level. The implication is that investment in executive advance will improve teaching quality. In a related development, the effect of executive advance on research was posited with the path coefficient of $0.155(p<001)$. Therefore, when executive advance goes up by 1 , faculty research skill goes up by 0.155

Meanwhile, the effect of level of mentoring on teaching and research skills are positive with the regression weight of $.130(p<0.001)$ and $.021(p<0.001)$ respectively. When mentoring goes up by 1 standard deviation, teaching and research skills goes up by 0.30 and 0.021 standard deviations respectively. The regression weight for mentoring in the prediction of faculty teaching and research performance is significantly different from zero at the 0.001 level. Furthermore, it is important to state that collaboration and academic linkage have a strong relationship with variables such as research and innovation and their effect is positive with coefficient value of $.028(p<0.05)$ and $.116(p<0.05)$ in that order. Evidently, when collaboration and academic linkage goes up by 1, research and innovation goes up by 0.028 and 0.116 . In other words, the regression weight for collaboration and academic linkage in the prediction of faculty development is significantly different from zero at the 0.001 level.

In another development, the effect of organisational learning on innovation and community service are positive with the regression weight of $.138(p<0.001)$ and $.107(p<0.001)$ respectively. When organisational learning goes up by 1 standard deviation, innovation and community service goes up by 0.138 and 0.107 standard deviations respectively. The regression weight for organisational learning in the prediction of faculty level innovation and community service are significantly different from zero at the 0.001 level. In another development, the effect of induction/orientation on community service is positive with the regression weight of $.091(p<0.001)$ therefore, when induction/orientation goes up by 1 standard deviation, community service goes up by 0.091 . Besides, the effect of induction /orientation on innovation 
was negative with path coefficient of -.169 $(p<0.05)$. Therefore, the regression weight for induction/orientation in the prediction of faculty innovation is not significantly different from zero at the 0.05 level. When the induction/orientation goes up by 1 , innovation goes down by -0.169 . However, the result was far from expectation.

Further results of the SEM analysis show the correlation between the independent variables (exe_advan; mentoring; collabo_Linkag; org_learning; induct_orient). The results showed close association exists between the tested independent variables. Further, the covariance between exe-advan and mentoring is estimated to be $.166(p<0.001)$; mentoring and collabo_linkag is estimated to be .177 ( $p<0.001)$; collabo_linkag and org_learning is estimated to be .238 $(p<0.001)$; org_learning and induct_Orient is estimated to be $.088(p<0.001)$; exe_advn and org_learning $=.198$ $(p<0.001)$; exe_advan and collabo_linkag $=.586(p<0.001)$; collabo_linkag and org_learining $=.238(p<0.001)$. Therefore, it is observed that Executive Advance, mentoring, Research Collaboration and Academic Linkages, Organisational Learning, and Induction and Orientation have positive effects on faculty performance which tends to promote competitive advantage

\section{Managerial Implications}

The study provided insight into the significant of strategic human resource development plans for effective performance, therefore, every faculty should be given an opportunity to develop their potentials for career growth and development. We can conclude that executive advance, mentoring, research collaboration and academic linkage, organisational learning and induction/orientation will have positive effect on teaching, research, innovation and community service. Therefore, the more academic staff develop their skills, the more their performance will be enhanced. The study supported the findings of Chadwick, and Raver (2015), Peretomode, and Chukwuma (2012), Louw- Potgieter (2012) and Lo and Ramayah (2011), who added that the quality of teaching and research tend to increase when academic staff are giving opportunity to attend conferences, workshops, seminars which will invariably improve and update their knowledge and skills to keep abreast of the trends of knowledge development in their discipline. This study tends to assist the stakeholders in the educational sector to fully understand the effects of strategic human resource development (executive advance, mentoring, research collaboration and academic linkage, organisational learning and induction/orientation) on faculty job performance (teaching, research, innovation and community service) which tends to promote organisation competitiveness. Meanwhile, it assists the policy makers and other stakeholders in educational sector to understand the significant relationship that exist between the strategic human resource development, performance and competitiveness.

\section{References}

Adeniji, A. A., Falola, H. O \& Salau, O. P. (2014). A Modelling relationship between Work Satisfaction and Faculty Performance in the Nigerian Private Universities, European Scientific Journal, Vol. 10(32), 63-80.

Amabile, T. M., Patterson, C., Mueller, J., Wojcik, T., Kramer, S. J. \& Odomirok, P. W. (2001). Academic-Practitioner Collaboration in Management Re-search: a Case of Cross-Profession Collaboration. Academy of Management Journal, Vol.44 (2), 418-431.

Bamford, C. (2011). Mentoring in the twenty-first century, Leadership in Health Services, Vol. 24(2), 150-163.

Bozeman, B., \& Feeney, M. K. (2007). Toward a Useful Theory of Mentoring: A Conceptual Analysis and Critique, Administration and Society, Vol. 39(6), 719-739.

Brew, A. (2010). Imperatives and challenges in integrating teaching and research. Higher Education Research and Development, Vol. 29(2), 139-150.

Chadwick, I. C. \& Raver, J. L. (2015). Motivating Organizations to Learn: Goal Orientation and Its Influence on Organizational Learning. Journal of Management Vol. 41(3), 957-985.

Darwin, A. (2000). Critical reflections on mentoring in work settings, Adult Education Quarterly, 50, 197-211.

DiBella, A., Nevis, E. and Gould, J. (1996). 'Understanding Organizational Learning Capability', Journal of Management Studies, Vol. 33(3), 361-379.

Emelo, R., (2009). Mentoring in tough times, Industrial and Commercial Training, Vol. 41(4), 207-211.

Falola, H. O., Osibanjo O. A, and Ojo, S I (2014). Effectiveness of Training and Development on Employees' Performance and Organisation Competitiveness in the Nigerian Banking Industry. Bulletin of the Transilvania University of Braşov Series V: Economic Sciences. Vol. 7 (56).

Francis, L. M., (2009) Shifting the shape of mentoring, Training and Development, Vol. 63(9), 36-60.

Gberevbie, D. E., Osibanjo, A. O., Adeniji, A. A., and Oludayo, A. O. (2014). An Empirical Study of Gender Discrimination and Employee Performance among Academic Staff of Government Universities in Lagos State, Nigeria. International Journal of Social, Human Science and Engineering Vol. (1), 101-108.

Giles, C., and Hargreaves, A. (2006). The sustainability of schools as learning organizations and professional learning communities during standard-based reform. Educational Administration Quarterly, 42, 124-156. 
Griffiths, R. (2004). Knowledge production and the research-teaching nexus: the case of the built environment disciplines. Studies in Higher Education, Vol. 29(6), 709-726.

Hegstad, C. D. \& Wentling, RM (2004). The development and maintenance of exemplary formal mentoring programs in Fortune 500 companies, Human Resource Development Quarterly, 15, 421-448.

Holland, C. (2009). Workplace mentoring: a literature review, Developed by Work and Education Research \& Development Services, New Zealand.

Iles, P, Preece, D. \& Chuai, X. (2010). Talent management as a management fashion in HRD: towards a research agenda, Human Resource Development International, Vol. 13(2), 125-145.

Judge, T. A. \& Kammeyer-Mueller, J. D., (2011). Implications of core self-evaluations for a changing organizational context, Human Resource Management Review, Vol. 21(4), 331-341.

Kruse, S. D. (2003). Remembering as an organizational memory. Journal of Educational Administration, Vol41 (1), $332-347$.

Leisyte, L., Enders, J., \& Boer, H. (2009). The balance between teaching and re-search in Dutch and English universities in the context of university governance reforms. Higher Education, Vol. 58(5), 619-635.

Lengnick-Hall, C. A \& Inocencio-Gray, J .L. (2013). Institutionalized Organizational Learning and Strategic Renewal: The Benefits and Liabilities of Prevailing Wisdom. Journal of Leadership \& Organizational Studies Vol. 20(4) 420-435.

Louis, K. S. (2006). Changing the culture of schools: Professional Community, Organizational Learning, and Trust. Journal of School Leadership, Vol. 16(1), 477-489.

Lo, M. C. and Ramayah, T. (2011). Mentoring and job satisfaction in Malaysian SMEs, Journal of Management Development, Vol. 40(4), 427-440.

MacGregor, L. (2000). Mentoring: the Australian experience, Career Development International, Vol. 5(4), 244-249.

Macfarlane, B. (2010). Changing Seascape of Higher Education Research: Forerunners, Pathfinders and Pathtakers. Paper presented at the Society for Research in Higher Education Newer Researchers' Conference.

Ndebele, C., (2013). New Staff Perceptions on an Academic Staff Induction Programme at a South African University: Lessons for Educational Development. Journal of Social Sciences, Vol. 36(2): 103-111.

Obisi Chris (2001), Employee development, Issues and dimensions, Unical Journal of public Administrator. Vol. 1(1).

Peretomode, V. F. \& Chukwuma, R. A. (2012). Manpower Development and Lecturers' Productivity in Tertiary Institutions in Nigeria. European Scientific Journal Vol. 8(13), 16-28.

Putz, D, Schilling, J, Kluge, A \& Stangenberg, C. (2012). Measuring organizational learning from errors: Development and Validation of an Integrated Model and Questionnaire. Management Learning Vol. 44(5) 511- 536.

Saxena, A. (2012). Evaluating Training and Development Programs in the Corporate Sector. Lotus Institute of Management, India, 1- 18.

Silins, H. C., \& Mulford, W. R. (2002). Schools as Learning Organizations. Journal of Educational Administration, Vol. 40(1), 425-446.

Weinberg, F. J. \& Lankau, M. J. (2011). Formal Mentoring Programs: A Mentor-Centric and Longitudinal Analysis, Journal of Management, Vol. 37(6), 1527-1557.

Whelan, E. \& Carcary, M. (2011). Integrating Talent And Knowledge Management: Where Are The Benefits? Journal of Knowledge Management, Vol. 15(4), 675-687. 